\title{
KENIKMATAN ESTETIS DALAM SENI SUATU TINJAUAN FILOSOFIS
}

\author{
Veronika Eny Iryanti \\ FBS, Universitas Negeri Semarang \\ E-mail: enyv@gmail.com
}

\begin{abstract}
Abtsrak
Estetika (estetik, Yunani: Persepsi indera) merupakan bidang yang mengkaji tentang keindahan, baik keindahan alam maupun seni. Sedangkan yang mengkaji tentang keindahan dalam seni sering disebut sebagai filsafat seni. Kenikmatan estetis dalam seni merupakan bidang dalam filsafat seni. Kenikmatan estetis dalam seni merupakan bentuk ontologi dalam seni. Di dalamnya mengadaikan proses estetis manusia dalam menangkap estetika seni. Estetika seni merupakan sifat dasar dari suatu karya seni. Manusia menangkap sinyal estettis tersebut sebagai sebuah rangkaian 'kerja' dari rasa. Seni menampilkan keindahan sebagaimana adanya dan manusia menangkap hal tersebut. Proses menangkap estetis tesebut sebagai sebuah proses yang filosofis. Filososfis di sini diandaikan adannya proses-proses yang panjang dalam diri manusia. Di sini rasa memainkan peran yang penting. Di samping rasa ada fantasi dari diri manusia sebagai makhluk yang mempunyai rasa estetis, dengan kadar yang berbeda-bede.
\end{abstract}

Kata Kunci: estetis, seni, kenikmatan, hasrat, fantasi.

\section{AESTHETIC ENJOYMENT IN ARTS A PHILOSOPHICAL STUDY}

\begin{abstract}
Abtsract
Aesthetics (estetik, in Greek: perception of senses) is a field of science which studies beauty, either natural beauty or arts. Meanwhile, a field of knowledge which studies beauty in arts is called Philosophy of Art, and aesthetic enjoyment is part of it. Aesthetic enjoyment is a kind of onthology in art which explains the aesthetic process of human beings in trying to understand aesthetic matters in art. Aesthetics in art is also the basic characteristic of an art work. Human beings understand this aesthetic signal as a series of work of feelings. Art performs beauty as human beings understand it. The process of understanding the aesthetic values is considered a philosophical process, as this requires such a long process within human beings. What is very important here is feeling. Besides, there is also fantasy within human beings as a creature that has aesthetic feeling although in different degrees.
\end{abstract}

Keywords: aesthetics, art, enjoyments, passion, fantasy

\section{PENDAHULUAN}

Seni merupakan bidang yang sangat khusus dibanding dengan bidang ilmu lainnya. Dikatakan demikian karena seni merupakan bagaian dari nilai (value), yang berintikan pada estetika. Estetika mengadaikan suatu bentuk pemahaman yang melibatkan rasa. 
Jangkauan rasa lebih luas daripada rasio. Dengan rasa maka seni dapat dinikmati. Kenikmatan seni merupakan kenikmatan estetis, yaitu suatu proses dalam diri manusia yang melibatkan rasa estetis manusia itu dalam rangka menangkap sinyal-sinyal estetis dari suatu karya seni.

Karya seni menampilkan suatu nuansa estetis dan manusia menangkap nuansa estetis tersebut sebagai sebuah proses value. Karya seni dengan value-nya, dapat diinterpretasi dengan sangat luas tanpa harus mempertimbangkan rasio. Manusia sebagai pencipta dan penikmat seni memainkan peran penting di dalam proses estetis. Peran tersebut seperti interpretasi atas suatu karya seni. Interpretasi tersebut sebagai suatu kenikmatan estetis.

Realitas estetis dalam seni diciptakan seniman sebagai bentuk kreasi dan kreativitas estetisnya. Namun, kenikmatan estetis muncul tidak begitu saja. Ada beberapa proses atau pun realitas estetis lain yang melingkupinya. Suatu kesan estetis tidak akan berdiri dalam ruan kosong, tanpa dimensi yang lain. Kenikmatan estetis dalam seni sebagai kesatuan utuh ruang lingkup estetis dalam karya dan senimannya. Kenikmatan estetis sebagai sebuah realitas filsafati. Ruang lingkup kenikmatan estetis tersebut seperti yang akan terpapar berikut ini.

\section{PENGERTIAN KENIKMATAN ESTETIS}

Seni atau karya seni merupakan suatu psiko-fisiknya organisme yang baru akan tumbuh dan hidup sepenuhnya di dalam jiwa penikmatnya. Seni berasal dari pengertian tentang penciptaan karya seni, yang telah dihasilkan suatu definisinya, sebagai: "kesan pengalaman fantasi seniman dalam kesadarannya akan orang-orang yang hidup sezamannya melalui perantaraan suatu bahan yang telah tersedia." Tanpa adanya kesadaran akan orang-orang yang hidup sejamannya, artinya tanpa sesama manusia yang dapat ikut serta menikmatinya, tentunya seni itu tidak bisa dibenarkan atau dengan kata lain karya itu tidak bisa dianggapnya sebagai seni. Seni memang sudah lama sebelumnya menjadi dasar perantara atau alat pergaulan antar sesama manusia. Bagi seniman cukuplah, pengenalan suatu lingkungan penikmat seni, yang walaupun samar-samar, lagi di bawah sadar, yang penting mereka ikut serta terlibat di dalamnya. Sesungguhnya tidak ada seniman yang berkarya merasa tergugah semangatnya, apabila dia tidak dapat memperkenalkan siapapun penikmatnya. Dorongan seni adalah dorongan informasi, jadi ia mengundang suatu publik yang dapat diberi informasi (Scruton, 1983:5). 
Sekarang apabila seniman mengungkapkan pengalamannya ke dalam kesadaran penikmatnya, artinya melalui perantaraan karya seninya yang objektif di dalam proses penciptaan itu, demikianlah kenikmatan itu tidak mungkin bisa lain kecuali mengalami itu kembali; suatu penciptaan ulang, sesuai dengan ukuran struktur tertentu dari penikmatnya. "Kenikmatan estetik" menurut hakikinya adalah suatu tiruan penciptaan yang dimodifikasi secara pribadi ini adalah suatu batasan pengertian yang luar biasa pentingnya, lagi produktif. Bila kita menjumpainya atau menjumpai keadaan semacam itu, kita harus menemukan tanda-tanda serupa dalam pengertian kenikmatan estetis seperti dalam pengertian penciptaan seni (Sheppard, 1988:10).

Di sini akhirnya ditemukan untuk pertama kalinya tanda-tanda pengalaman fantasi secukupnya. "Seni adalah kesan pengalaman fantasi seniman" Dalam pengalaman itu ada terkandung; baik yang berupa kegiatan merasakan itu maupun yang merasakan fantasi cipta. Dalam penyelaman fantasi itu orang menangkap kesan yang diterimanya dari luar, dan yang akan menuju ke pusat pengalaman, serta mengatur itu, dan membentuknya ke dalam dimana legalitas pribadinya merasakan. Di dalam gambaran fantasi diekspresikan pula pribadi seniman yang mencipta. Gambaran fantasi seperti itu sekarang mempengaruhi kembali ke seluruh psiko-fisiknya pribadi tersebut. Menangkap perasaannya serta menggiringnya ke arah gerak-gerak kesan, dan di situ sertamerta diukir, digambarkan dan dibentuk perasaan pengenalan fantasi yang ditimbulkannya. Jadi fantasi itu yang akan bekerja mencipta seni (Beardsley, 1988:40).

Sungguh-sungguh serasi apa yang telah kita temukan dalam kenikmatan estetis, di dalamnya terkandung juga tanda-tanda pengalaman fantasi secukupnya. Kesan-kesan luar yang dipaparkan dalam karya seni objektif itu mula-mula akan ditangkap dan diolah oleh yang menyelami fantasi penikmat, artinya legalitas tertentu penikmat akan digambarkan di dalamnya. Sekarang gambaran fantasi yang dihasilkan mempengaruhi kembali seluruh psiko-fisik pribadi penikmat, dan tidak menaruh perasaan di dalam gerakan. Tetapi sekarang tidak ada kegiatan fantasi cipta di sini, yang bisa menciptakan gambaran yang objektif dari pengalaman. Oleh karena itu di dalamnya dibedakan antara manusia pencipta dengan manusia bukan pencipta. Penikmat estetik dihadapkan betul-betul pada fantasi yang dirasakannya. Tanpa itu kenikmatan estetis hampir tidak mungkin. Oleh karena itu pada umumnya akan dikupas dan dilaksanakan seperti apa yang, terkait di bagian lain, manusia yang miskin fantasi juga tidak punya hubungan dalam ke arah seni, tidak juga akan menginginkan hal tersebut, lagi tidak akan tahu tentang itu (Sheppard, 1988:17). 
Tetapi hal ini bagi penyelam fantasi penikmat estetik masih jauh lebih mudah daripada senimannya sendiri untuk itu. Ini hal menangkap kesan alami, yang menurut aturannya merupakan kesan pengetahuan asing bagi seniman, yang begitu banyak mengganggu dan menghambat tanda-tanda itu padanya. Semua hambatan emosional itu harus diatasi penyelam fantasi seniman, apa yang dia lihat, suatu kesamaan pengetahuan, tetapi yang mengangkat tanda-tanda yang selaras kekesatuan; dengan kata lain: mengatur kesan tersebut ke dalamnya.

Yang menyelami fantasi penikmat estetik sebaliknya mendapatkan suatu kesan yang sudah diatur di dalam karyaseni, jadi suatu gambaran pribadi manusia. Kegiatan itu hanya terjadi di dalamnya, tekanan pribadi seniman pencipta itu hanya untuk menyesuaikan kepribadiannya sendiri. Ikut mengalami dan ikut mencipta, dari penikmat akan semakin sepadan dengan pengalaman serta kreasi yang diujudkan oleh seniman ke dalam karyaseni itu, akan semakin sepadan pula kedua pribadi itu (Beardsley, 1988:36).

Bahan karyaseni itu, jadi anekaragam pengenalan itu berpengaruh pada fantasi, sebaliknya bentuk karya seni berpengaruh sekaligus pada perasaan penikmat. Tetapi, keduanya secara seragam akan tertangkap penyelam fantasi itu dan tercetak ke dalam bentuk individual penikmat. Sejauh itu pula ikut merasakan fantasi penikmat yang kreatif, lagi dasar pembentukkan aprioris (hanya berdasarkan teori saja) fantasi tersebut akan berdaya-guna pada ujud bentuk individual itu (Scruton, 1983:17).

\section{HASRAT ESTETIS}

Seperti dapat digambarkan sebagai suatu keadaan keinginan ataupun hasrat yang kuat, keadaan yang sungguh-sungguh umum dari sikap estetis, artinya dari kesempurnaan kegiatan dalam yang tak terkendali. Demikian telah disebutkan terutama mengenai penciptaan seni, bahwa hal tersebut khususnya diiringi suatu perasaan keinginan estetis pada awal stadium dan pada akhir stadium (seperti penerimaan, kehamilan dan pembentukan), yang kita ketahui sebagai hasrat akan fungsi dan tugas yang tak terkendali.

Keinginan atau hasrat estetis ini sekarang menjadi khas untuk kenikmatan estetis. Karena penikmat akan menaruh simpati pada suatu gambaran pribadi manusia di dalam karyyaseni tersebut, jadi seorang teman, gambaran watak yang lama/mirip, yang legalitas umumnya serasi dengan legalitasnya sendiri. Oleh karenanya kesan itu tidak akan menjadi rintangan yang berlawanan akan penangkapannya, dan menjadikannya milik sendiri, karenanya lagi yang ikut merasakan fantasi itu dapat pula mengungkapkan apa yang serba 
harmonis, apa yang dicita-citakan oleh kepribadian itu, ia bebas menggambarkan legalitasnya sendiri ke dalam kesan itu. Jadi, penikmat mengalami seperti penciptanya sendiri keinginan estetis itu sebagai fungsi yang tak terkendali. Rasa senang yang estetis itu menarik baik secara teoretis maupun secara praktis pada obyek karyaseni itu. Memang itu merasakan suatu kebebasan, suatu ketidakminatan akan kesenangan estetis, yang dengan pengalaman yang tak terkendali telah menghubungkan seluruh cita-cita kegiatan dalam. Kant memang benar, bila dia mengatakan: keinginan estetis itu suatu rasa senang yang tidak menarik (Hosper, 1982:195).

Kant juga benar, jika dia menemukan alasan keinginan estetis itu dalam kesubjektifan, kecocokan formal akan kesan bagi daya tangkap kita, yang memang berakibat suatu permainan yang harmonis bebas pula pada daya tangkap itu. Dia terutama menonjolkan di bawah kekuatan itu selain imaginasinya juga akal budinya, memang bisa dengan mudah membangkitkan pendapat yang salah, seolah-olah mengundang perasaan akan keinginan estetis itu, terutama kecocokan formal kesan itu untuk pengenalan manusia (Barker, 1983:72). Namun kebenarannya, yaitu sesuai dengan kenyataan, jadi kecocokan subjektif akan kesan itu untuk penangkapan melalui keikutsertaan rasa kita pada fantasi yang terlepas dari fungsi yang tak terkendali akan keinginan atau hasrat itu. Karena sampai pada cita-cita pribadi yang serba harmonis ke reaksi kegiatan fantasi, begitu berarti kecocokan formal untuk pengertian ikut merasakan fantasi, jadi imaginasi, bersama itu pula dengan kecocokan formal untuk kesibukan seluruh pribadinya pada umumnya (Hosper, 1982:235).

Kant pun tidak menjawab pertanyaan ini, bagaimana kecocokan subyektif bisa masuk ke dalam karya seni. Dari asal mula kita berpijak, telah dapat kita berikan jawaban yaitu pada pelaksanaan penciptaan seni. Subjektif itu, kecocokan formal karya seni, artinya sesuai dengan kenyataan bagi legalitas yang menangkap kepribadian itu, dari mana itu berasal, bahwa karyaseni tidak bisa lain kecuali sebagai suatu gambaran kegiatan fantasi seniman, yang legalitas kemanusiaan umumnya diungkapkan/ diekspresikan hingga yang paling sempurna. Sesungguhnya mengenai baik imaginasi maupun gambaran daya anganangan akan penciptaan serif, baik itu yang ikutserta merasakan maupun fantasi yang kreatif . Aturan itu adalah khayalan dan imitasi legalitas umum dari pribadi manusia dalam kesibukannya ikut merasakan dan fantasinya yang kreatif; hal tersebut sebagai prinsip pembentukkan yang apriori (berdasar teori saja) (Kant, 1987:45). Oleh karena itu secara singkat dapat ditegaskan bahwa, produk karya seni adalah kegiatan karya fantasi, maka hal 
itu harus sesuai dengan prinsip pembentukkan aprioris fantasi formal yang sesuai pula untuk setiap fantasi yang ditangkapnya (Kant, 1987:67). .

Karena penikmat dengan bantuan keikutsertaannya merasakan fantasi, di mana kegiatan penangkapan itu mengacu pada legalitas manusia secara umum, sama seperti pada pembentukkan fantasi cipta, karya seni itu tertangkap, oleh karena itu dia harus merasakan persesuaian subyektif itu. Dan perasaan itu tidak lain adalah rasa senang estetis.

Keinginan estetis itulah sebagai keinginan yang berasal dari kebebasan dalam yang sempurna terhadap keinginan yang tidak estetis, yang dari satu pihak dapat lolos dari kegiatan yang mengikat. Demikian di situlah menjadi bagian bidang teoritis, keinginan perasaan yang tidak terikat apapun dan keinginan pengenalan akan objeknya (keinginan akan kebenaran), dan pada bidang praktis, jadi keinginan dan bertindak: yaitu keinginan akan keserasian objektif dan keinginan akan perbuatan yang baik. Itu semua bukannya kebebasan atau rasa senang yang membosankan, melainkan sebuah eksisitensi objek yang bagaimanapun merasakan rasa senang yang menarik (Hermeren, 1983:38).

Memang dengan ini tidak mengatakan, bahwa itu lama sekali tidak ada hubungannya ke arah seni. Objek-objeknya dapat lebih banyak tampil sebagai bahan karyaseni, baik secara langsung maupun melalui reaksi asosiatif yang penting. Dapat dipikirkan, misalnya, pada warna pada seni lukis dan persepsi nada dan seni musik, kaitannya dengan pemikiran dan pengertian moral dalam seni pantun dan seterusnya. Tetapi kemudian ia terharu karena bentuk itu, yang seharusnya terukir masuk ke dalam organ yang berkaitan, kalau itu secara estetis berdaya guna. Akhirnya, manusia semua tidak tertarik akan objek-objek perasaan melulu atau pengenalan atau pun kemauan, melainkan sebagai pengenalan fantasi, sebagai sarana pengekspresian pribadi seniman (Husser, 1985:14).

Perasaan atau persepsi warna itu sendiri, persepsi nada yang hubungannya dengan pancaindera, daya cium, selera, rasa-rabaan, bagi diri sendiri hanya dapat menyenangkan, namun tidak pernah menyenangkan secara estetis. Itu baru dapat dirasakan pertama, apabila manusia luluh dalam ke satuan fantasi, jadi manusia seolah ditempatkan di dalam organ perantara yang umum. Akibat dari estetis adalah selalu berbentuk reaksi, artinya reaksi antara hubungan elemen satu-sama lain. Dalam bentuk pengenalan fantasi dapat berbentuk daya cium dan rasa estetis ,yang; sifatnya menonjol; hal tersebut sama seperti apa yang di tunjukkan pada bidang seni pantun, yang sering kali cukup dikerjakan dengan selera, khususnya pengenalan akan bau (misalnya dari harumnya bunga). Jadi, kesenangan estetis merupakan pengaruh dari bentuk seni, yang merupakan gambaran legalitas umum 
pribadi manusia, sekaligus secara formal berarti kecocokan subjektif bagi pandangan fantasi penikmat (Sibley, 1983:15).

\section{KENIKMATAN SENI DAN ALAM ESTETIS}

Di atas telah diuraikan mengenai kesenangan estetis pada karya seni. Bagaimana sekarang hubungannya dengan kenikmatan estetis dari alam? Bagaimana itu terpikirkan, satu bagian alam dapat membawa kita ke kebebasan dalam, sama sempurnanya seperti pada sebuah karya seni? Di dalam bagian alam tidak ada seniman yang legalitas umum pribadi kemanusiaannya ditekankan. Bagaimana itu akhirnya bisa dirasakan oleh penikmatnya? Apa yang dipunyai untuk diciptakan, misalnya, sebuah pemandangan dengan legalitas umum manusia?

Pertanyaan di atas dapat dijawab, kalau orang berpegang pada pandangan mata, apa yang telah kita katakan perbedaannya antara hubungan satu dengan lainnya: bukan kesan luarnya yang berakibat rasa estetis kita, melainkan gambaran fantasi, yang manusia miliki. Kalau manusia melihat sebuah karya seni, kemudian digambarkan pribadi manusia, masih dengan bantuan perasaan fantasi manusia, kemudian disamakan gambaran fantasi yang nantinya mengundang manusia ke dalam kesenangan estetis.

Hal yang sama berlaku pula dari kesan alam. di dalamnya dicari kepribadian kita untuk digambarkan dalam fantasi perasaan kita. Dan itu akhirnya akan berhasil pula, bila dipandang secara objektif, kesan yang kita organisasi, artinya pandangan yang dipersatukan tidak dengan berat hati, persatuan itu selalu menolak tanda-tanda yang merintangi, serta memandang yang subjektif, kalau manusia terlalu meletakkan dasar teoretis hubungannya dengan sikap praktis secara sepihak.

Oleh karena itu tentukan kesan alam itu pada apa yang sedang diselenggarakan, tidak menentang pandangan fantasi seadanya, melainkan menunjukkannya sendiri ke kesatuan yang tertentu, yang memudahkan pandangan kita, demikianlah fantasi kita akan berhasil melihat bagian alam fantasi seadanya, itu sama sekali dalam gambaran pribadi manusia itu sendiri. Dan gambaran fantasi itu akan terjadi, karena itu berasal dari keadaan bebas yang empurna, yang merangsang kesenangan estetis itu pada diri kita. Tema pokok kenikmatan estetis manusia akhirnya hanya selalu merupakan gambaran fantasi manusia sendiri saja, pekerjaan manusia sendiri, juga kebebasan yang tak terkendali (Beardsley, 1988:60). 
Problema manusia akhirnya mengantar manusia ke pertanyaan itu kembali: bagaimana mungkin itu bisa digambarkan, fantasi manusia terutama kepribadian manusia di luar dunia, entah itu di dalam seni ataupun alam? Untuk itu dijawab dalam arti sebenarnya menurutu filsafati personalis: kemampuan menyelami atau ketabahan umum. Kemampuan introsepsi, termasuk pula kemampuan mewujudkan pribadinya di dunia, jadi kemampuan mengembangkan diri ke sifat-sifat pribadi manusia, yang tidak disalurkan ke tempat lain yang lebih banyak kita terima daripada apa yang manusia berikan (Beardsley, 1988:51).

Jadi penikmat seni dan penikmat alam keduanya sama-sama serasi satu sama lain, bahwa mereka dalam kebenaran menikmati suatu gambaran fantasi melalui rangsangan kesan seni atau lebih tepat lagi dikatakan kesan alam yang akan diciptakan penikmat. Mereka hanya dibedakan di dalamnya, bahwa kesan seni memudahkan terjadinya gambaran fantasi, persamaannya ke kesan alam, karena itu telah diorganisasi oleh seniman secara pribadi.

Hal tersebut sekarang jelas, bahwa kesan alam akan lebih mudah dinikmati secara estetis, semakin jelas itu mengantar manusia ke suatu legalitas yang lama seperti yang miliki, demikian akan menjadi sangat mudah watak yang alamiah, seperti manusia, binatang dan tumbuh-tumbuhan dapat ditangkap secara estetis, diantara mereka yang pertama adalah manusia. Karena pada sesama manusia paling mudah dapat merasakan. Kesan-kesan alam sebaliknya tidak diorganisasi seperti telah diutarakan di atas; hanya bisa kemudian dinikmati secara estetis, apabila dalam keanekaragamannya muncul suatu kesatuan tertentu, jadi boleh dikatakan suatu tahap pendahuluan dari pelaksanaan, dan bila di lain pihak menghendaki kekuatan fantasi manusia, perlu melihat ke dalam legalitas manusia sendiri dalam kesan itu (Hosper, 196).

Kemampuan untuk menikmati alam secara estetis seperti itu, baraimanapun sudah ada pada setiap orang, termasuk kemampuan berintrosepsi ke watak pribadi manusia. Namun itu masih dapat berkembang dan meningkat terutama melalui kenikmatan seni. Kalau manusia, misalnya, sering melihat pemandangan alam dalam seni, jadi boleh dikatakan mengenakan mata yang betul-betul telah dipersiapkan demikian dari seniman, kemudian manusia akan belajar memandang itu dalam alam, dan lama-kelamaan juga dengan mata yang khusus semacam itu. Menikmati seni mengajarkan kepada yang bukan seniman ke kenikmatan alam, di sisi lain alam menarik seniman ke seni (Hosper, 112). 


\section{TAHAP KENIKMATAN ESTETIS}

Sekarang dapat dlihat jalannya kenikmatan estetis agak lebih serius lagi, demikian akan selalu semakin jelas, bahwa ternyata menurut hakikinya tidak lain selain merupakan suatu imitasi atau tiruan (mimesis) yang dimodifikasi secara pribadi. Sebenarnya dapat membuktikan dengan tahap-tahap yang betul-betul akurat, seperti pada penciptaan seni. Hal tersebut seperti yang terdapat dalam Scruton (1983:21-30) dan Bearsdley (1988:xviilxii).

Pertama. Dapat kita gambarkan hal tersebut secara tepat seperti pada proses penciptaan seni sebagai "kehamilan ide karya seni". Penikmat menyerahkan dirinya kepada karya seni dengan perasaan fantasinya, dan dia mengalami secara serentak kesenangan estetis pada perasaannya, apakah karya itu sesuai atau tidak baginya.

Kedua. Pada saat kehamilan ide karya seni itu yang berperan adalah "tahap pertumbuhan". Penikmat tumbuh masuk seluruhnya ke dalam karya dari pusat pengalamannya kepada suatu pengabdian yang samasekali melupakan dirinya. Di depan perasaan fantasirnya tumbuh gambaran karyaseni yang semakin besar semakin lengkap memenuhinya. Ia akan serentak terharu atas ide itu dari tahap pertama, di pusat sanubarinya yang sekarang membuat semua pengaruh halus unsur-unsur: harmonis, ritmis dan melodis berlaku bagi perasaan yang umum 'tahap pertumbuhan'.

Ketiga. "Tahap kematangan", penikmat telah menjadikan karyaseni itu milik sendiri di dalam fantasinya - sesuai legalitasnya sendiri, di mana dia telah merasa terharu akan. Terbukanya pengaruh-pengaruh resminya, demikian dia telah mencapai tahap kematangan. Rangsangan perasaan yang betapa kuatpun akan terlepaskan juga. Ia ini untuk diujudkan telah matang. Namun dia tidak akan terdorong oleh fantasi ciptanya untuk mewujudkan itu, jadi tidak bisa mengekspresikan dirinya ke dalam karyaseni, demikian dia mendesaknya ke penilaian estetis, yang dia temukan pernyataan itu pada keputusan estetis.

Ketiga tahap pertama itu merupakan pengalaman perasaan sederhana seperti kesadaran yang samar-samar pada penciptaan. Penikmat menyerahkan dirinya sama sekali tanpa sadar pada pengaruh karya seni. Keempat. Yang berjalan pada keputusan estetis adalah tahap kesadaran analisa. Hal itu sesuai dengan "tahap sketsa" pada penciptaan, yang berlaku pada pembentukkan. Penikmat mencari dirinya, sejauh mungkin pengaruh perasaan dari bentuk akal biasa untuk membuatnya sadar. Dia mencoba mengalihkan pengaruh bentuk dari pengadaan karya seni. 
Kelima. Pada proses pembentukkan yang sebenarnya akhirnya cocok dengan penikmatan nilai estetis pada penciptaan, jadi formulasinya dari keputusan estetis. Bagaimana seniman membentuk akunya ke dalam karya seni, demikian pulalah ditekankan nilai penikmat seni, dirinya/akunya ke dalam putusan itu (Hauser, 1982:3-8).

\section{KESIMPULAN}

Manusia dan seni merupakan entitas yang tidak dapat dipisahkan. Manusia yang berkarya seni atau sebut saja seniman, berkreasi sesuai dengan daya estetis yang dimilikinya. Dengan daya estetis ini seniman memberikan deformasi estetis atas objekobjek karyanya. Manusia lain (penikmat) akan menikmati keindahan yang ditampilkan dalam karya seni. Proses penikmatan estetis tersebut melibatkan beberapa hal, seperti: rasa, fantasi, dan kesadaran. Proses-proses tersebut bersifata filosofis, artinya melibatakan ontologi yaitu suatu di belakang yang riil. Indera penglihatan untuk melihat keindahan seni visual (seni rupa) dan indera pendengaran untuk mendengar musik, atau keduanya memberikan kontrubusi dalam menikmati pertunjukan drama dan teater. Namun kenikmatan estetis dalam seni lebih ke arah 'di belakang yang riii', di luar rasio dan hanya ditangkap oleh rasa (yang masuk dalam ranah value).

\section{DAFTAR PUSTAKA}

Barker, Stephen, "Kant on Experiencing Beauty", in Fisher, John, 1983, Essay On Aesthetics: Perspectives of the Work of Monroe C. Beardsley, Philadelphia: Temple University Press, hal. 69-85.

Beardsley, Monroe C., 1988, Aesthetics: Problems in the Philosophy of Criticsm, Indianapolis - Cambridge: Hackett Publishing Company, Inc.

Hauser, Arnold, 1985, The Sociology of Art, translated by Kenneth J. Northcott, Chicago London: The University of Chicago Press.

Hermeren, Goran, "The Autonomy of Art", in Fisher, John, 1983, Essay On Aesthetics: Perspectives of the Work of Monroe C. Beardsley, Philadelphia: Temple University Press, hal. 35-49.

Hospers, John, 1982, Understanding the Art, New Jersey: Prentice-Hall, Inc., Englewood Cliffs.

Kant, Immanuel, 1987, Critique of Judgment, Indianapolis: Hackett Publishing Company. 
Scruton, Roger,1983, The Understanding Aesthetic, London and New York: Mathuen.

Sheppard, Anne, 1987, Aestherics: An Intoduction to the Philosophy of Art, Oxford: Oxford University Press. 
Kenikmatan Estetis dalam Seni: Suatu Tinjauan Filosofis 